\title{
Observations on the behaviour of the European fiddler crab Uca tangeri
}

\author{
Birgit Wolfrath*
}

Department of Marine Botany, Institut für Meereskunde, Düsternbrooker Weg 20, D-24105 Kiel, Germany

\begin{abstract}
The annual and tidal cycle of behaviour of UCa tangeri (Eydoux, 1835) was studied over a 2 yr period in the Ria Formosa on the Portuguese Algarve coast. U. tangeri settles on the mudflats as well as in the nearby zone of Arthrocnemum spp.. Individuals smaller than $27 \mathrm{~mm}$ carapace width live close to the creek; larger crabs inhabit the salt marsh zone. Newly settled crabs are found in the middle of the mudflat. A surface temperature of at least $18^{\circ} \mathrm{C}$ is necessary for $U$. tangeri to become active on the sediment surface. Hence activity shows a clear annual cycle: the months March to July are used for courtship and reproduction. During this time crabs change colour from brown to orange and purple. Large migrations to other mudflats take place from August to October, whereas crabs stay inside their burrows from November to March. During low-tide periods, crab activity can be differentiated into food uptake, courtship, or migration and burrowing.
\end{abstract}

\section{INTRODUCTION}

Fiddler crabs of the genus $U_{c a}$ (Brachyura, Ocypodidae) are found in salt marshes, mangrove regions, mudflats and sandy beaches of nearly all tropic and subtropic regions of the world. While many studies have been performed on American and Indian $U_{C a}$ species, little is known about the European fiddler crab Uca tangeri (Eydoux, 1835). Previous studies have mostly dealt with sexual and courtship behaviour of the Andalusian U. tangeri population (Altevogt 1957 , Hagen 1962). In her description of the species, Crane (1975) only mentioned a small population in Portugal. This is not correct; $U$. tangeri is frequent throughout the eastern Algarve coast and is one of the dominant species in the intertidal zone of the Ria Formosa in Portugal. This study describes annual and tidal activity, population structure and dynamics of an $U$. tangeri population in the Ria Formosa.

\footnotetext{
- Present address: Information, Redaktion und Außenbeziehungen, Institut für Weltwirtschaft, Dusternbrooker Weg 120, D-24105 Kiel, Germany
}

\section{MATERIAL AND METHODS}

Study site. The investigations were performed from August 1989 to November 1990 at Ramalhete station in the Ria Formosa on the Portuguese Algarve coast near the city of Faro. A $2 \times 3 \mathrm{~m}$ area located on a mudflat near a small creek was studied. The mudflat rises about $0.5 \mathrm{~m}$ above water level at low tide and merges into a salt marsh zone of Arthrocnemum spp., where Uca tangeri is commonly found. The mudflat is exposed for about $6 \mathrm{~h}$ twice a day which especially in summer leads to very high temperatures in the upper 2 to $3 \mathrm{~mm}$ of the sediment (up to $32^{\circ} \mathrm{C}$ in August). During the winter months (November to February), all mudflats are covered with a thick layer of long filamentous green algae. This layer starts to decay at the end of January and is totally gone by early April. More detailed information on the biotope of the Ria Formosa is given by Universidade do Algarve (1986), Belchior (1988), and Wolfrath (1992a).

Observations over the year showed that the Mediterranean climate of the Algarve, with mild springs and autumns, hot and dry summers with southwest winds, relatively mild winters with much rain and 


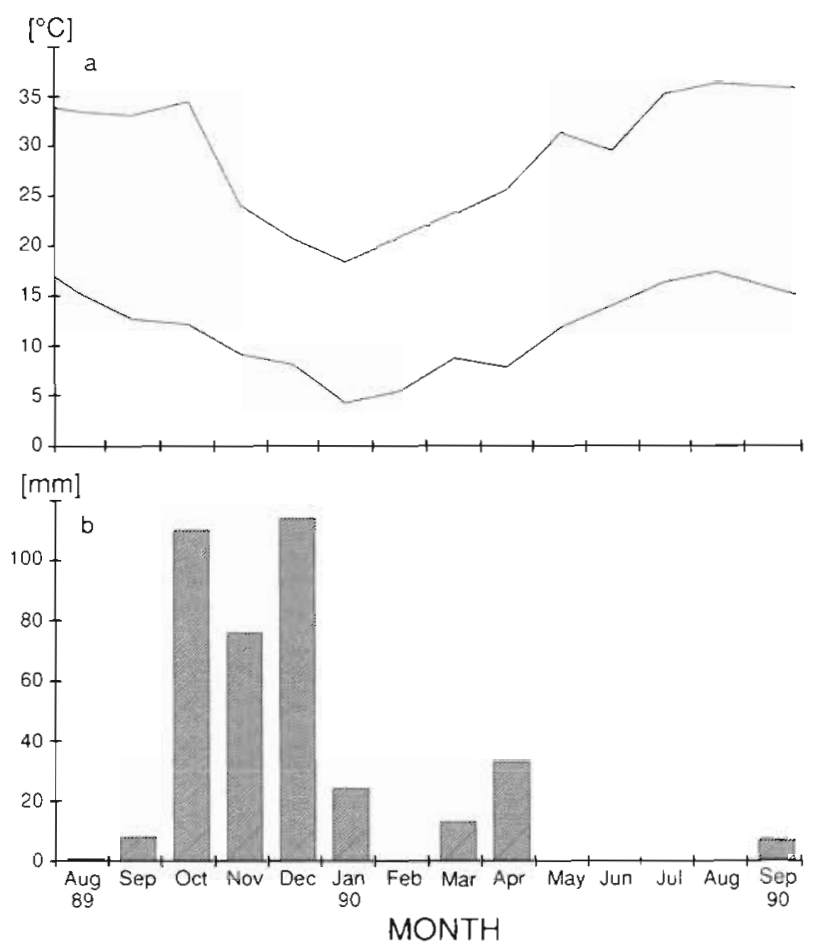

Fig. 1. (a) Air temperature and (b) rainfall intensity in the eastern Algarve (Portugal) from August 1989 to September 1990. Data from the meteorological station of Faro International Airport

northeast winds (Fig.1a, b), had a strong influence on the annual activity of $U_{C a}$ tangeri.

Investigations. Observations on behaviour and population dynamics were made at daytime and nighttime at low tide, twice a week over a 16 mo period. Crabs were identified with waterproof, nontoxic paint on the back of their carapace; burrow entrances were marked with wire rods with little flags of coloured tape. While flags stayed intact for the period of study, carapace marks had to be renewed every $4 \mathrm{wk}$. None of the markings caused an obvious change in crab behaviour. During each observation period, the number of male and female animals and burrow number and state (vacated, inhabited, closed, opened) were registered. Once a week carapace width and length and for male crabs the length of the major chela of 20 randomly selected specimens were measured and animal wet weight (ww) was determined with a spring balance (accuracy $\pm 0.1 \mathrm{~g}$ ).

Studies required capture of unharmed individuals of Uca tangeri without disturbing the habitat. In previous studies capture was performed by hunting the crabs on the surface, at the entrance of their burrows, by digging them up or by sieving the sediment (Altevogt 1957, Miller 1961, Krebs \& Valiela 1978, Bergin 1981, Robertson \& Newell 1982a, b, Hoffman et al. 1984,
Bertness 1985, Thurman 1985, Morgan 1987, Christy 1989). All these methods disturb the substrate and are furthermore inefficient. Therefore a special trap was developed for these observations.

The trap (Fig. 2a, b) is a tube of nontransparent plastic (PVC) about the same diameter as a crab burrow. A 1 -way mesh flap hangs freely from a wire rail which is attached to the PVC. It is important that the mesh flap is able to move freely. A small screw inserted through the PVC tube prevents the flap from swinging towards the burrow. It is necessary to use a mesh for the flap of the trap so that light passes into the burrow, so that the flap appears to be a normal exit to the crab inside. Since Uca tangeri is not able to climb the smooth inner surface of the PVC tube, a 'track' consisting of a mixture of coarse sand and non-toxic paint is painted on
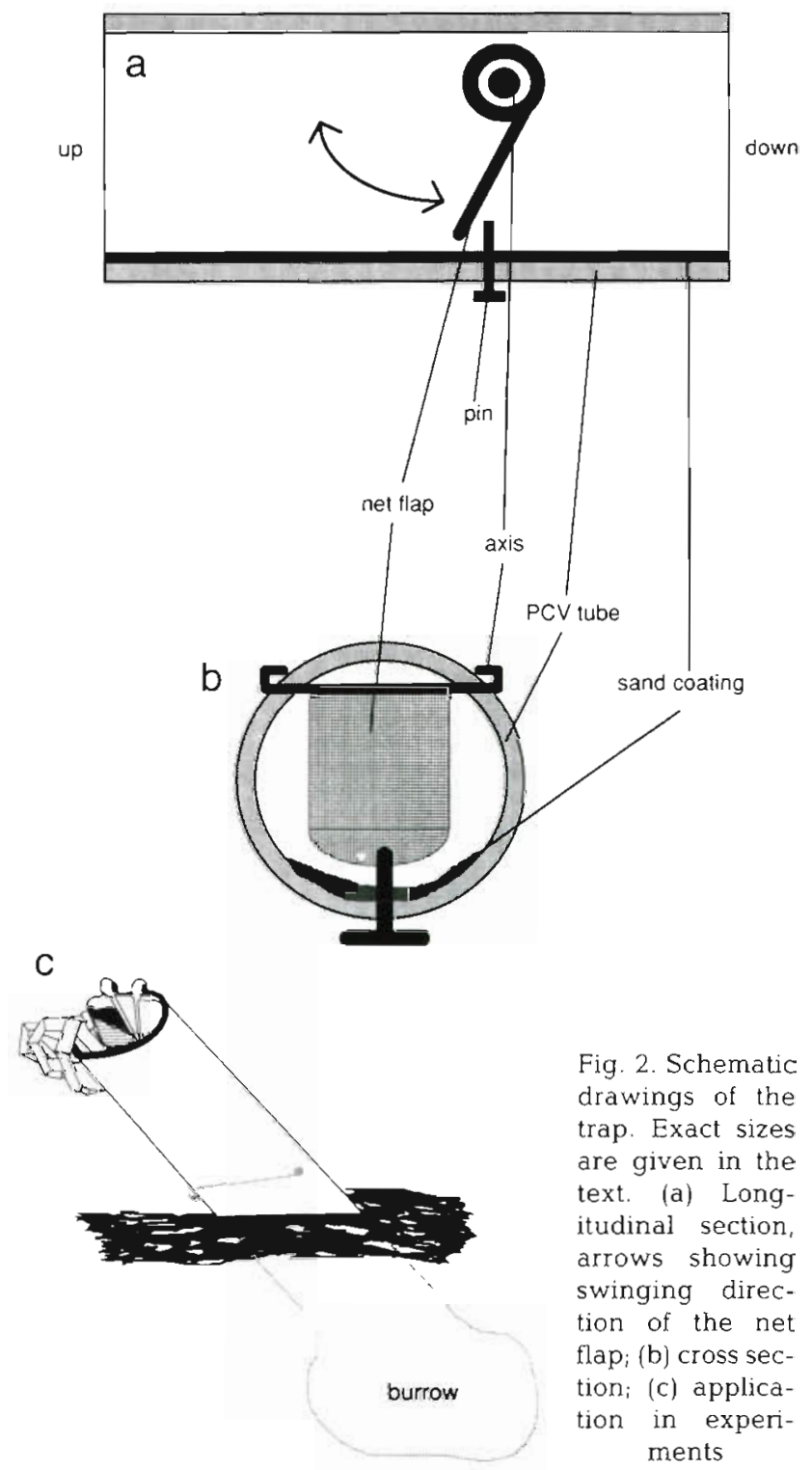
inside the tube. Length and diameter of the trap depend on the size of the crab to be captured. The tube length should be at least twice that of the crab including its legs. The tube diameter should exceed the burrow entrance by at least 2 or $3 \mathrm{~cm}$. Traps with a diameter of $5 \mathrm{~cm}$ and a length of $15 \mathrm{~cm}$ were used to capture crabs with a carapace width of $3 \mathrm{~cm}$ and more. For smaller crabs, the traps were of $3 \mathrm{~cm}$ diameter and $9 \mathrm{~cm}$ length. The mesh size of the flap was $1 \times 1 \mathrm{~mm}$ for both trap sizes.

The application of the trap in the field is based on the fact that $U_{C a}$ tangeri, like other fiddler crabs, seeks refuge in its burrow in case of danger. The trap is placed on the entrance of the burrow containing the wanted crab and inserted slightly into the ground. The axis of the PVC tube should be parallel to the burrow (Fig. 2c). The crab pushes the net flap open when leaving the burrow, passes into the upper part of the tube, and the flap closes behind the crab. The crab cannot escape through the upper opening of the tube and can easily be collected in the trap. The only disturbance to the sediment is a mark of the tube left around the entrance of the burrow. Crabs were released into their original habitat (and even into their original burrows) after measurement.

The time needed to capture 1 individual varied from 5 to $15 \mathrm{~min}$. Working with 6 traps made it possible to capture and mark about 45 crabs in $1 \mathrm{~h}$. Crabs needed to be dug out of the sediment only in winter.

Meteorological data (air temperature, wind direction and rainfall) are averages of daily registrations of the weather station at Faro International Airport.

\section{RESULTS}

\section{Population structure and dynamics}

The highest numbers of Uca tangeri, with up to 17 ind. $\mathrm{m}^{-2}$ visible on the surface, were counted during the courtship period, from the beginning of March to the end of June. Beginning in July, the number of active crabs decreased until surface activity totally stopped at the beginning of November (Fig. 3). During the entire year the male to female ratio of active crabs visible on the surface was nearly constant, with about $40 \%$ females and about $60 \%$ males.

Population size structure changed from smaller to larger crabs at the end of summer. While from November to the end of January the most frequent carapace width was 18 to $22 \mathrm{~mm}$, crabs measured 26 to $29 \mathrm{~mm}$ between February and June and up to $36 \mathrm{~mm}$ from July to the end of September. Crabs smaller than $10 \mathrm{~mm}$ were only found from the end of September to the beginning of November (Fig. 4). Throughout the

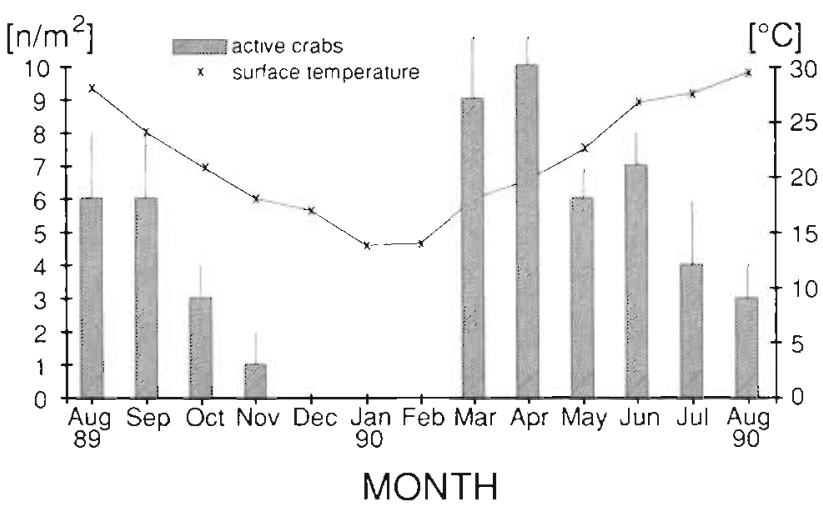

Fig. 3. Surface temperature of the sediment and number of active Uca tangeri from August 1989 to September 1990. Given is an average of observations twice a week. Vertical bars show SE. $\mathrm{n}=$ number of crabs

year crabs with carapace width $<27 \mathrm{~mm}$ were found in the first $1.5 \mathrm{~m}$ of the mudflat as seen from the creek; newly recruited crabs lived in the relatively flat upper $0.5 \mathrm{~m}$ of this zone in the middle of the mudflat. Large crabs (carapace width $>27 \mathrm{~mm}$ ) occurred in the upper regions of the mudflat near and in the salt marsh zone (ANOVA, $p=0.05$ ) (Fig. 5).

Growth of Uca tangeri is isometric. Carapace width (cw) shows a constant relation to carapace length (cl) and length of the male major claw (mcl) that can be expressed with the following regressions $(n=50)$. The intercept between male and female crabs are significantly different (ANOVA, $\mathrm{p}=0.05$ ):

$$
\begin{array}{lll}
\text { males: } & \mathrm{cl}=-4.8+1.0 \mathrm{cw} & (\mathrm{r}=0.98) \\
& \mathrm{mcl}=-18.7+2.2 \mathrm{cw} & (\mathrm{r}=0.98) \\
\text { females: } & \mathrm{cl}=-5.0+1.0 \mathrm{cw} & (\mathrm{r}=0.98)
\end{array}
$$

For better comparison of changes in wet weight of Uca tangeri during the year a ratio ( $\mathrm{ww} / \mathrm{Cw}$ ) was calculated for male and female crabs (Table 1). This ratio did not vary with crab size and served to determine the wet weight for indivuals of both sexes of the same size $(25 \mathrm{~mm}$ ) (Fig. 6). Calculations showed that wet weight of $U$. tangeri varied significantly throughout the seasons. From the end of November to the beginning of March crabs weighed about $30 \%$ less than individuals of the same size weighed between June and the end of August. Because of their large waving claws, male crabs clearly weighed more than female crabs (ANOVA, $\mathrm{p}=0.05$ ). While male $U$. tangeri reached maximum wet weight in May, female wet weight increased until the end of August, probably because of the additional weight of developing eggs carried under the abdomen. The influence of the developing eggs was also visible in females, with ovigerous females weighing clearly more than females of the same size without eggs. Correlation of carapace width to wet 

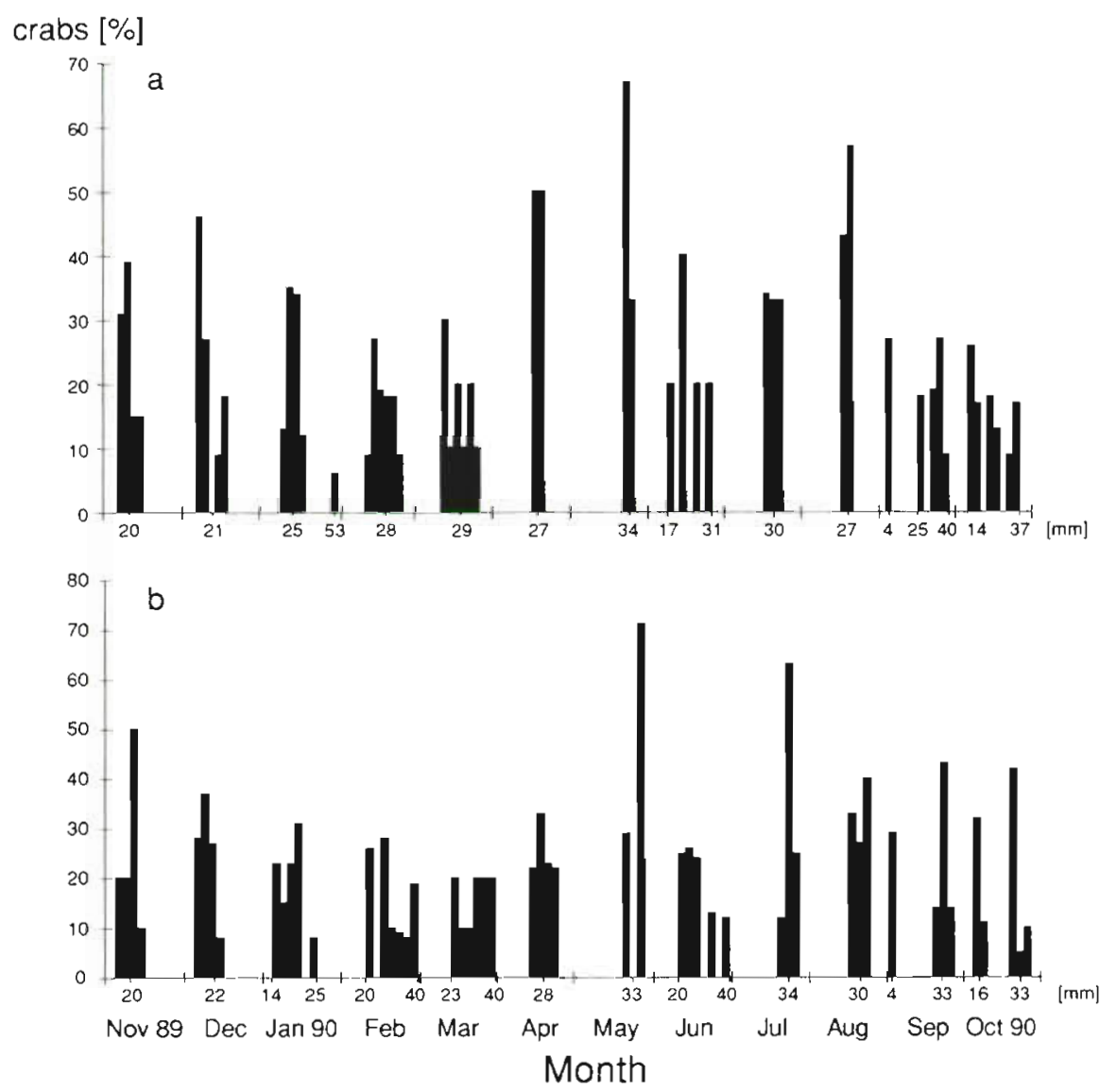

Fig. 4. Carapace width of Uca tangeri from November 1989 to November 1990, showing cohorts of $2 \mathrm{~mm}$ size. Number of crabs is 50 $(=100 \%)$ each month in (a) and (b). (a) Females; (b) males

weight was not as good as for size, because the amount of water attached to the crab and, in females, the weight of the eggs influence the measurement. The following equations can be calculated $(n=50)$ :

$\begin{array}{lll}\text { males: } & \ln (w w)=-0.83+0.11 \mathrm{cw} & (\mathrm{r}=0.94) \\ \text { females: } & \ln (w w)=-1.23+0.12 \mathrm{cw} & (\mathrm{r}=0.97)\end{array}$

\section{Time of burrow inhabitation}

Observations of the marked individuals showed that about $80 \%$ of the crabs inhabited the same burrow for

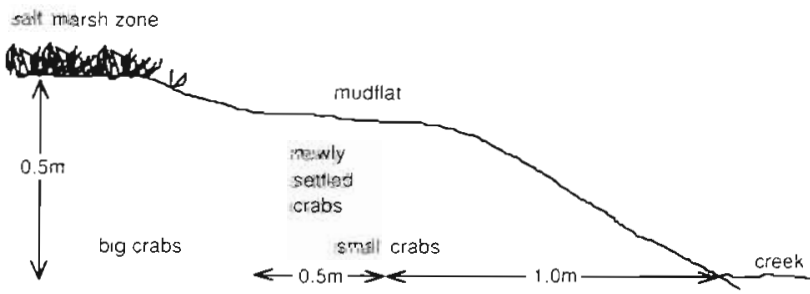

Fig. 5. Transect of the mudflat with the study area. Given are the data of crab distribution. Exact sizes of Uca tangeri in the text
$1 \mathrm{wk}$. Nearly $11 \%$ of the crabs lived in the same burrow for about $2 \mathrm{wk}$. Burrow occupations $<1 \mathrm{wk}$ or $>2$ wk were observed only exceptionally (Table 2). Often crabs changed burrows with one another, either voluntarily or after a fight. The burrow habitation pattern was the same for male and female crabs.

Table 1. Uca tangeri. Ratio of wet weight (ww) to carapace width (cw) for males and females from November 1989 to November 1990. Mean of weekly measurements of 20 individuals of each sex \pm SE

\begin{tabular}{|lcc|}
\hline Month & \multicolumn{2}{c|}{ Fw/cw ratio } \\
& & Male \\
\hline Nov 1989 & $0.17 \pm 0.07$ & $0.29 \pm 0.08$ \\
Dec 1989 & $0.14 \pm 0.06$ & $0.21 \pm 0.02$ \\
Jan 1990 & $0.23 \pm 0.01$ & $0.25 \pm 0.09$ \\
Feb 1990 & $0.24 \pm 0.05$ & $0.39 \pm 0.05$ \\
Mar 1990 & $0.35 \pm 0.01$ & $0.42 \pm 0.01$ \\
Apr 1990 & $0.43 \pm 0.03$ & $0.57 \pm 0.07$ \\
May 1990 & $0.45 \pm 0.03$ & $0.76 \pm 0.04$ \\
Jun 1990 & $0.45 \pm 0.13$ & $0.60 \pm 0.06$ \\
Jul 1990 & $0.48 \pm 0.07$ & $0.60 \pm 0.11$ \\
Aug 1990 & $0.60 \pm 0.11$ & $0.58 \pm 0.07$ \\
Sep 1990 & $0.41 \pm 0.03$ & $0.55 \pm 0.10$ \\
Oct 1990 & $0.35 \pm 0.04$ & $0.42 \pm 0.04$ \\
\hline
\end{tabular}




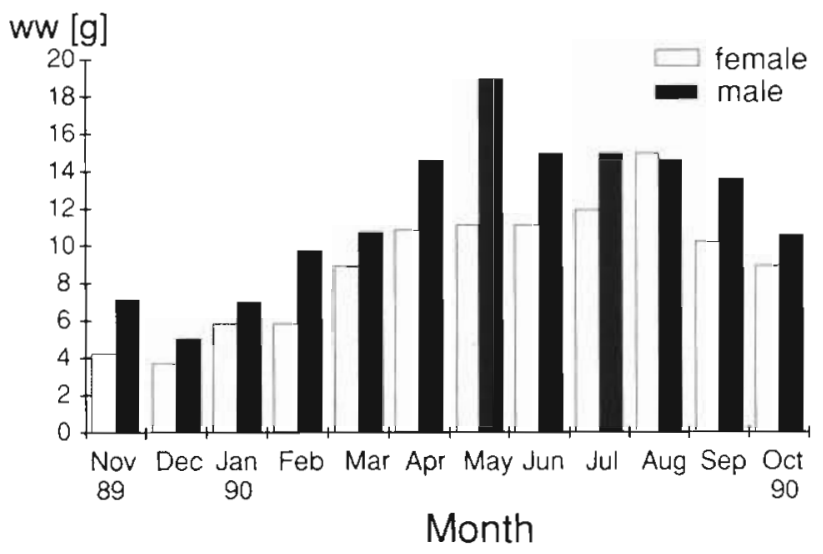

Fig. 6. Wet weight of Uca tangen for individuals of $25 \mathrm{~mm}$ carapace width, calculated with the $\mathrm{cb} / \mathrm{w}$ w ratio from November 1989 to November 1990

Table 2. Uca tangeri. Percentage of crab population in the study area using the same burrow for 1 wk or more, March to October 1990. $\mathrm{n}=$ total number of crabs in study area that month

\begin{tabular}{|lrrrrrrrrrrr|}
\hline $\begin{array}{llll}\text { Month } \\
(1990)\end{array}$ & 1 & 2 & 3 & 4 & 5 & 6 & 7 & 8 & 9 & 10 \\
\hline Mar & 70 & 19 & 10 & 1 & - & - & - & - & - & 92 \\
Apr & 81 & 14 & 2 & 2 & 1 & - & - & - & - & 94 \\
May & 88 & 6 & 4 & 2 & - & - & - & - & - & 114 \\
Jun & 75 & 12 & 9 & 2 & - & 1 & 1 & - & - & 155 \\
Jul & 82 & 10 & 5 & - & 3 & - & - & - & - & 78 \\
Aug & 88 & 8 & 2 & - & - & 2 & - & - & - & 43 \\
Sep & 82 & 9 & 3 & - & - & - & - & 1 & 1 & 92 \\
\hline
\end{tabular}

One burrow was inhabited for about 3 mo before it was definitively vacated. The burrows were not only used by Uca tangeri but also by other crab species living in the Ria Formosa, like Pachygrapsus marmoratus and Carcinus maenas. Vacated burrows decayed rapidly and filled up with sediment in about 2 or $3 \mathrm{wk}$.

\section{Courtship and mating}

In March the carapace of Uca tangeri changed from its usual brown shade to brighter colours, marking the onset of the courtship period. Dorsal carapace turned light yellow-brown to orange, whereas the ventral side became purple. The upper part of the walking legs also turned purple, the lower part and the minor chela became orange, eye stalks turned light green. Only the major chela of the male crabs stayed white all year. Ovigerous females changed colour to a dark purple during egg development. $U$. tangeri kept these colours until end of August, when crabs started to fade back to their usual shade by middle of September.

The most conspicuous behaviour in courtship of Uca tangeri, as in all other Uca species. was the waving of the big claw by males, while making exactly the same movements with the minor claw. Waving was observed during courtship only, never during the rest of the year. Males with a major chela longer than about $60 \mathrm{~mm}$ used only the dactylus for waving. During nighttime activity and in the salt marsh zone, males did not wave but struck the big claw on the sediment surface. Waving behaviour could be differentiated into 3 degrees, depending on distance of the female and the corresponding excitement of the male and the courtship zone as described by Hagen (1962) for an $U$. tangeri population in Andalusia, Spain. In contrast to Hagens (1962) studies only about $10 \%$ of the registered copulations in the Ria Formosa took place on the surface, while about $90 \%$ of the crabs copulated inside a burrow.

\section{Combat}

Throughout the annual activity phase male Uca tangeri fought for burrows and the surrounding territory. In many cases wandering males hit the entrance of an inhabited burrow with the major claw which made the burrow owner appear immediately at the surface for a fight. Most of the time the opponents only threatened each other by spreading their big claw in front of the body (Fig. 7), followed by forward jumps by one of the males and snapping of the big claw.

In case this behaviour was not sufficient to drive away the rival, combat took place. The big claws were engaged and the opponents tried to push each other backwards or aside (Fig. 8). In extreme cases the

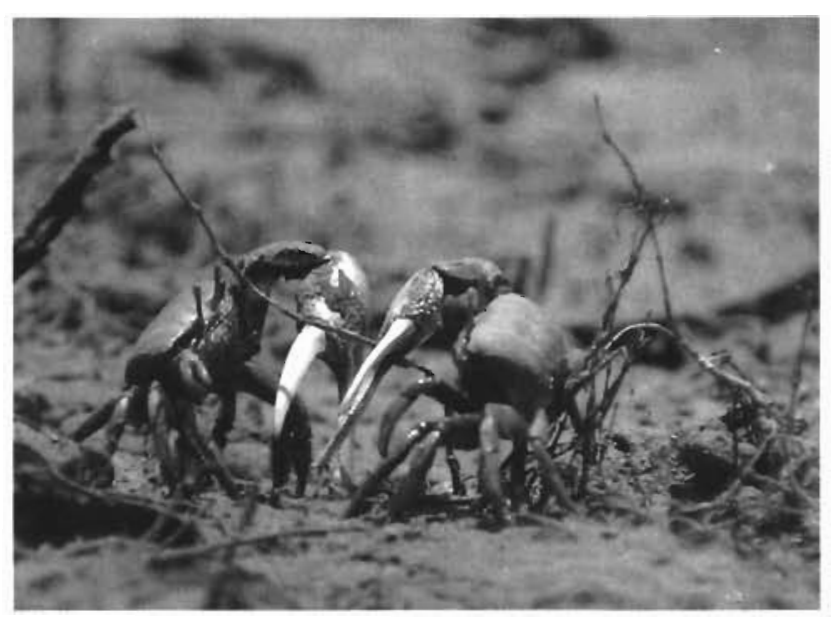

Fig. 7 Combat of 2 male UCa tangern: threatening with opened waving claws. Original size 


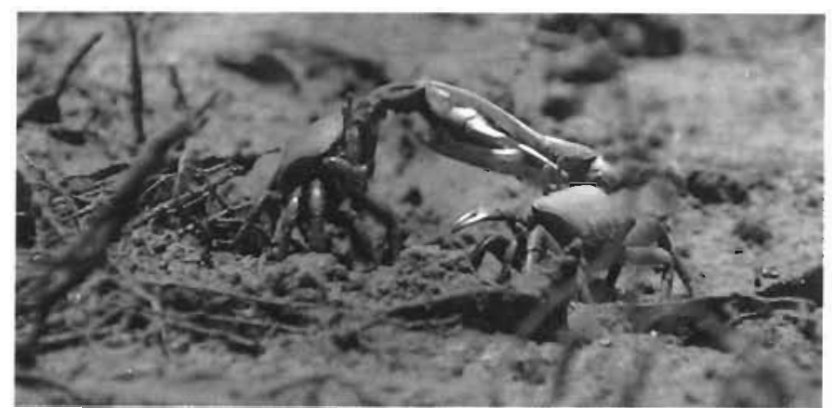

Fig. 8. Two male Uca tangeri with engaged waving claws pushing each other during combat. Size reduction $1.5 \times$

weaker male was thrown aside by the stronger one (Fig. 9), but normally the inferior disengaged its big claw and ran away. The superior male followed for a short distance and then returned to its burrow.

Female Uca tangeri also fought for burrows. They pushed each other aside or backwards until one gave up.

\section{Tidal cycle of activity}

Like all fiddler crabs Uca tangeri is only active at the surface at low tide, by night as well as by day. Burrow entrances were opened about $15 \mathrm{~min}$ after the beginning of low tide when the mudflat was exposed. The following 5 to $10 \mathrm{~min}$ crabs stayed in the entrance nearly motionless. During this time the slightest disturbance made the crabs retreat into the burrow at once and stay there for up to $15 \mathrm{~min}$. Without disturbance about 1 to $1.5 \mathrm{~h}$ of intensive feeding followed, with the feeding range around the burrow increasing up to $1 \mathrm{~m}$. Roughly the next hour was used for burrowing activities (such as repair, lengthening an existing burrow or

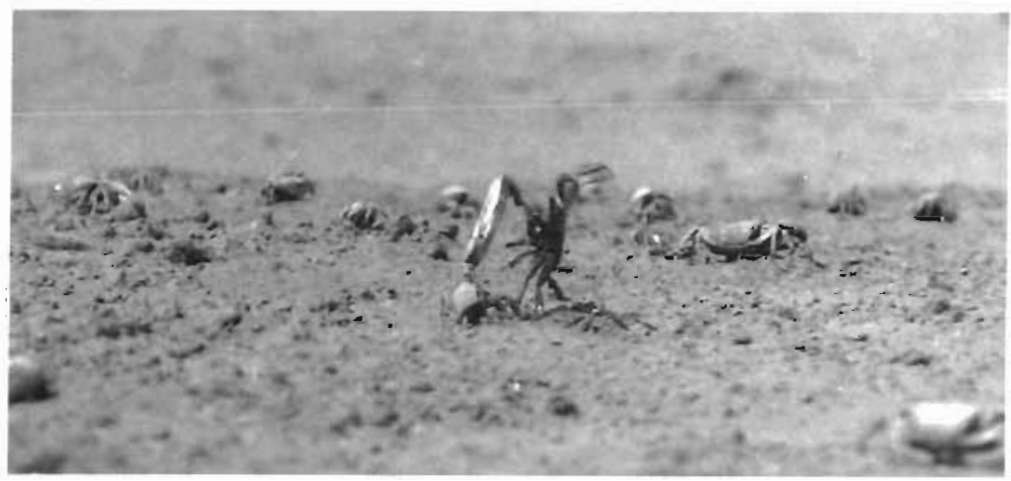

Fig. 9. Combat of 2 male Uca tangeri: inferior male thrown aside by the superior. Size reduction $2.5 \times$ digging a new one) followed by a phase of either courtship (March to end of June) or large migrations to other mudflats (July to end of October). Surface activity of $U$. tangeri always ended with feeding about $1 \mathrm{~h}$ before the mudflat was flooded. At this time many crabs were observed sitting motionless at the burrow entrance with their dorsal side pointing towards the sun. This so called 'posing' posture has been described by Hagen (1962) and Crane (1975). About 15 min later crabs started to plug the burrow entrance with mud and about 10 min before the mudflat was flooded all crabs had retreated.

\section{Annual cycle of activity}

Annual activity started at the end of the rainy season in the middle of March, when the upper sediment layer had reached a temperature of at least $18^{\circ} \mathrm{C}$. Courtship and reproduction took place until end of June. During the following months crabs undertook large migrations (up to $500 \mathrm{~m}$ ) on and between the different mudflats. At the beginning of October the first newly recruited individuals with a carapace width of 3 to $4 \mathrm{~mm}$ could be seen. Annual surface activity of $U_{c a}$ tangeri ended with the first rain and decreasing sediment temperatures at the beginning of November. During winter crabs stayed inside the closed burrows. The entrances were opened about every 2 wk without the crab becoming visible at the surface.

\section{DISCUSSION}

The structure of the Uca tangeri population in the Ria Formosa showed large crabs to live in or close to the salt marsh zone. The reason for this distribution may be the content of organic substance in the sediment that is clearly much higher in the salt marsh zone than on the mudflat (Wolfrath 1992b). Therefore, the salt marsh zone may be more attractive to the crabs. Because $U$. tangeri fight one another for burrows, bigger and hence stronger individuals have the advantage of occupying the best zones. Smaller crabs have to live in the less attractive zones.

The regressions resulting from growth measurements indicate that carapace width and length of male and female $U_{c a}$ tangeri increase at the same rate (slope = 1) but that female crabs are consistently wider per unit of length, probably for reasons related to body shape and egg production 
The highest numbers of active individuals were observed during courtship from March to the end of June. At this time probably all crabs living in the study area were active each low tide period and hence could be counted. During the rest of $U_{C a}$ tangeris annual activity many crabs wandered long distances and hence could not be assigned to one population in particular. At the end and at the beginning of the annual active period many crabs stayed inside their burrows.

Migrations of the adult Uca tangeri to other mudflats may prevent overcrowding of an area receiving newly recruited crabs and also enable the wandering crabs to move to new regions.

A special behaviour of Uca tangeri is the inactivity from November to March, when crabs stay in their burrows. It seems crabs do not feed during this time, as individuals in winter clearly lost weight compared to crabs of the same size in summer. $U$. tangeri probably utilises stored energy. The only activity of $U$. tangeri visible in winter is the opening of the burrow entrance about once a week. The oxygen inside the burrow may be used up in this time and hence has to be renewed. Because of crab movements inside the narrow burrow 'old' air from the inside is exchanged against 'new' air from the surface. After air exchange is finished, the burrow entrance is closed again. It is not clear whether the crab is able to lower its metabolism level while staying inside the burrow. Vernberg (1959) showed in his studies with various Uca species that oxygen uptake rate decreased during starvation periods and when air temperature decreased. In their experiments with $U$. pugnax Webb \& Brown (1961) found that crab respiration rate was about $50 \%$ less in winter than in summer.

Waving by male Uca tangeri obviously serves for courtship only, because it was never observed during the rest of the year. In contrast combat took place all year and in both sexes. It seems that each individual claims a burrow and defends it against other crabs (see Altevogt 1957, Greenspan 1980). Crabs also keep a 'feeding zone'. If another crab comes too close, males threaten by pointing the opened big claw towards the other, while females jump in the other one's direction.

In his studies on Uca tangeri in Andalusia Hagen (1962) nearly exclusively saw copulations on the surface. Males without a burrow also mated. In the Ria Formosa $U$. tangeri mated on the surface too, but most copulations took place after a male made a female follow it to the burrow. In no case was mating of a male without a burrow or mating inside a female's burrow observed. Hence, a burrow seems to be a prerequisite for successful mating by males. It seems as if in the Ria Formosa the normal courtship behaviour of $U$. tangeri, where the male waving allures the females to follow them into the burrow for copulation (i.e. Hagen 1962,
Crane 1975, Zucker 1986), is partly separated from the actual copulation. The reason may be that $U$. tangeri does not seem to have natural predators in the Ria Formosa. Although there is a large population of herons, none of the birds was observed hunting $U$. tangeri. Rats also do not seem to prey on $U$. tangeri. Their tracks could be seen everywhere but no remains of crabs eaten by rats were found (pers. obs.).

Acknowledgements. The author thanks S. A. Gerlach and D. Barthel for their open ears for discussions on the subject and their critical reading of the manuscript and S. X. Muzavor, K. v. Bröckel, B. Lembke and A. Petersen for their help in Portugal. This study was done within the frame of a GermanPortuguese research project (MFU 0563/4) and was supported by the Bundesministerium für Forschung und Technologie, the Deutscher Akademischer Ausstauschdienst and the Portuguese Ministèrio dos Negòcios Estrangeiros.

\section{LITERATURE CITED}

Altevogt, R. (1957). Untersuchungen zur Biologie, Ökologie und Physiologie indischer Winkerkrabben. Z. Morph. Ökol. Tiere 46: 1-110

Altevogt, R. (1957). Beiträge zur Biologie und Ethologie von Dotilla blanfordi (Alcook) und Dotilla myctiroides (MilneEdwards) (Crustacea, Decapoda). Z. Morph. Ökol. Tiere 46: $369-388$

Belchior, J L. (1988). Faro e a Ria Formosa. Graphica Almondina, Torres Novas, Portugal

Bergin, M. E. (1981). Hatching rhythms in Uca pugilator (Decapoda: Brachyura). Mar. Biol. 63: 151-158

Bertness, M. D. (1985). Fiddler crab regulation of Spartina alterniflora production on a New England salt marsh. Ecology 66: 1042-1055

Christy, J. H. (1989). Rapid development of megalopae of the fiddler crab Uca pugilator reared over sediment: implications for models of larval recruitment. Mar. Ecol. Prog. Ser. 57: $259-265$

Crane, J. (1975). Fiddler crabs of the world. Ocypodidae: Genus Uca. Princeton Univ. Press, Princeton

Greenspan, B. N. (1980). Male size and reproductive success in the communal courtship system of the fiddler crab Uca rapax. Anim. Behav. 28: 387-392

Hagen, H.-O. v. (1962). Freilandstudien zur Sexual- und Fortpflanzungsbiologie von Uca tangeri in Andalusien. Z. Morph. Ökol. Tiere 51: 611-725

Hoffman, J. A., Katz, J., Bertness, M. D. (1984). Fiddler crab deposit-feeding and meiofaunal abundance in salt marsh habitats. J. exp. mar. Biol. Ecol. 82: 161-174

Krebs, C. T., Valiela, I. (1978). Effect of experimentally applied chlorinated hydrocarbons on the biomass of fiddler crab Uca pugnax (Smith). Estuar. coast. mar. Sci. 6: $375-386$

Miller, D. C. (1961). The feeding mechanism of fiddler crabs, with ecological considerations of feeding adaptions. Zoologica 46: 89-101

Morgan, S. G. (1987). Adaptive significance of hatching rhythms and dispersal patterns of estuarine crab larvae: avoidance of physiological stress by larval export? J. exp. mar. Biol. Ecol. 113: 71-78

Robertson, J. R., Newell, S. Y. (1982a). Experimental studies of particle ingestion by the sand fiddler crab Uca pugilator (Bosc). J. exp. mar. Biol. Ecol. 59: 1-21 
Robertson, J. R., Newell, S. Y (1982b). A study of particle ingestion by three fiddler crab species foraging on sandy sediments. J. exp. mar. Biol. Ecol. 65: 11-17

Thurman, C. L. II (1985). Reproductive biology and population structure of the fiddler crab Uca subcylindrica (Stimpson). Biol. Bull. 169: 215-229

Universidade Do Algarve (1986). Parque natural da Ria Formosa. Plano de ordenamento: propostas e regulamentaçao (documento provisorio). Serviços De Documentaçao E Informaçao, Faro

Vernberg, F. J. (1959). Studies on the physiological variation between tropical and temperate zone fiddler crabs of the genus Uca. II. Oxygen consumption of whole organisms.

This article was submitted to the editor
Biol. Bull. 117: 163-184

Webb, H. M., Brown, F. A. Jr (1961). Seasonal variations in $\mathrm{O}_{2}$-consumption of Uca pugnax. Biol. Bull. 121: $561-571$

Wolfrath, B. (1992a). Burrowing by the fiddler crab Uca tangeri in the Ria Formosa in Portugal and its influence on the sediment structure. Mar. Ecol. Prog. Ser. 85: 237-243

Wolfrath, B. (1992b). Field experiments on the feeding of the European fiddler crab, Uca tangeri. Mar. Ecol. Prog. Ser. 90: $39-43$

Zucker, N. (1986). On courtship patterns and the size at which male fiddler crabs (genus Uca) begin to court. Bull. mar. Sci. 38: $384-388$

Manuscript first received: January 20, 1993

Revised version accepted: July 8, 1993 